SCIENTIFIC REPORT

\title{
Serious eye injuries caused by bottles containing carbonated drinks
}

\author{
F Kuhn, V Mester, R Morris, J Dalma
}

Br J Ophthalmol 2004;88:69-71

\begin{abstract}
Aim: To analyse serious eye injuries caused by bottles containing pressurised drinks.

Methods: Retrospective review of the databases of US, Hungarian, and Mexican eye injury registries.

Results: In the combined database (12 889 injuries), 90 cases $(0.7 \%)$ were caused by bottle tops or glass splinters. The incidence varied widely: $0.3 \%$ (United States), 3.1\% (Hungary), and $0.9 \%$ (Mexico), as did the agent. Champagne bottle corks were responsible in 20\% (United States), $71 \%$ (Hungary; $\mathrm{p}<0.0001$ ), and $0 \%$ (Mexico). Most eyes improved, but $26 \%$ remained legally blind.

Conclusions: The presence of warning labels on champagne bottles appears to reduce cork related eye injuries, as does using plastic bottles and caps.
\end{abstract}

B ottles containing pressurised fluid are potentially hazardous, even under normal circumstances. ${ }^{1-3}$ We present data on 90 such injuries from standardised surveillance systems in three countries-United States, Hungary, and Mexico.

\section{PATIENTS AND METHODS}

We retrospectively reviewed the databases of the US eye injury registry (USEIR, surveillance arm of the American Society of Ocular Trauma), and two of its international affiliates, the Hungarian (HEIR) and the Mexican eye injury registries (MEIR). In the USEIR model, initial and 6 month follow up information on both outpatients and inpatients is collected electronically (useironline.org and weironline.org) on all types of serious trauma ${ }^{45}$ using the Birmingham Eye Trauma Terminology (BETT) system. ${ }^{6}$

Only unintentional injuries occurring under "normal circumstances" were included in this study. Fischer's two sided exact test was used for statistical analysis.

\section{RESULTS}

Results are presented in table 1.

\section{DISCUSSION}

The first report $^{7}$ on unintentional eye injuries from bottles containing pressurised drinks was followed by many from several countries from Sri Lanka to the United States, ${ }^{1-3}{ }^{7-23}$ but no population based study is available. One review from India found that $15 \%$ of inpatient trauma cases were the result of bottle explosion. ${ }^{2}$ In a hospital based study $1.2 \%$ had such an aetiology in Kuwait, ${ }^{1}$ while a $2 \%$ rate was found in a 19 hospital survey in Israel. ${ }^{14}$ In our databases, $0.23 \%$ (USEIR) to $0.9 \%$ (HEIR) to $0.5 \%$ (MEIR) of cases had such an aetiology. The true incidence is thought to be much higher. ${ }^{1123}$

The material used for packaging pressurised fluids determines the injury risk. Glass is breakable, especially after wall thinning, ${ }^{19}$ and is responsible for the most severe cases. In our study, $38 \%$ of injuries, and almost all open globe trauma, were caused by glass splinters. Conversely, plastic and metal cans pose little danger: we found no related injury among the 12889 cases. Use of plastic bottles and screwcaps helps reduce the incidence of bottle related injuries: their annual number and rate gradually decreased in the USEIR from seven $(0.9 \%)$ in 1991 to one $(0.2 \%)$ in 1997 , and we noticed similar trends in Hungary and Mexico. The US Consumer Product Safety Commission (CPSC) estimated that 32000 people were treated in emergency rooms for bottle related trauma in 1974; a recent search conducted at our request on the CPSC database found only 12 such injuries in 1990 and five in 2000. A similar search of the National Electronic Injury Surveillance System database identified 22 cases in 1990 and seven in 2000.

The pressed metal top with corrugated edge, however, remains a threat, especially if the opener is not readily available. ${ }^{2}$ Roll-on caps reduce the risk of injury.

The proportion of trauma caused by cork/cap versus glass varies by country. Glass was responsible for $87 \%$ in Kuwait, ${ }^{1}$ as opposed to $24 \%$ in Germany ${ }^{21}$ and $20 \%$ in Israel. ${ }^{18}$ Based on available data, it is impossible to determine the causes of this disparity, although we suspect higher glass use in Kuwait.

Among bottle tops, the champagne bottle $\operatorname{cork}^{813}{ }^{18-20}$ remains the main culprit. A $750 \mathrm{ml}$ champagne bottle contains 4.125 litres of carbon dioxide with a pressure of 6.2 bar-almost three times higher than a typical car tyre's (Champagne France Information Bureau, 2002); this can shoot the 30 g cork up to 13 metres. The blinking reflex offers no help: from the typical opening distance of $60 \mathrm{~cm}$, the cork needs less than 0.05 seconds to reach the eye. We found no champagne bottle cork related injury in the MEIR, a $0.06 \%$ rate in the USEIR, and a $2.2 \%$ rate in the HEIR $(\mathrm{p}<0.0001)$. Since Hungarians do not drink disproportionately more champagne than Americans, there must be another explanation for this disparity.

In the United States, most champagne bottles carry conspicuous warning labels (fig 1), explaining the dangers to the eye and showing the correct way of bottle opening. Even if a bottle has no such warnings, the person is likely to be aware of the threat from previous occasions. No champagne bottle in Hungary has a warning label.

The ocular impact from the cork occurs at approximately $100 \mathrm{~atm}$ at $60 \mathrm{~cm} .{ }^{8}$ Since the energy is transmitted by a blunt object, contusion or rupture may ensue. ${ }^{6}$ Among the 23 cases we identified in the literature ${ }^{820}$ no rupture was reported; we found two ruptures among the 43 injuries in our series. Three of our 66 cases $(5 \%)$ resulted in penetrating injury caused by shattered prescription glass.

Among 37 eyes in the HEIR, $71 \%$ had injury involving the posterior segment, and of those with adequate follow up, 17\% remained legally blind with only 54\% reaching 20/40 or greater final vision. These numbers underline the need to prevent champagne bottle cork injuries. 


\begin{tabular}{|c|c|c|c|}
\hline & USEIR & HEIR & MEIR \\
\hline Study period & $\begin{array}{l}1 \text { January } 1982- \\
31 \text { December } 1999\end{array}$ & $\begin{array}{l}1 \text { January 1989- } \\
\text { 31 December } 1995\end{array}$ & $\begin{array}{l}1 \text { June } 1992- \\
31 \text { May } 2002\end{array}$ \\
\hline All cases in database & 10310 & 1664 & 915 \\
\hline Bottle related & $\begin{array}{l}30 \text { eyes of } 30 \\
\text { patients }(0.3 \%)\end{array}$ & $\begin{array}{l}52 \text { eyes of } 52 \\
\text { patients }(3.1 \%)\end{array}$ & $\begin{array}{l}8 \text { eyes of } 8 \text { patients } \\
(0.9 \%)\end{array}$ \\
\hline Men (\%) & 67 & 53 & 86 \\
\hline Age (years) & $24(2-53)$ & $36(2-70)$ & $29(11-55)$ \\
\hline Bystanders (\%) & 26 & 22 & 50 \\
\hline Ágent & $\begin{array}{l}\text { Glass: } 24(80 \%) ; \\
\text { champagne bottle } \\
\text { cork: } 6(20 \%)\end{array}$ & $\begin{array}{l}\text { Glass: } 5 \text { (10\%); cap: } \\
10 \text { (19\%); champagne } \\
\text { bottle cork: } 37 \text { (71\%) }\end{array}$ & $\begin{array}{l}\text { Glass: } 5(63 \%) \text {; cap: } 3 \\
(38 \%)\end{array}$ \\
\hline $\begin{array}{l}\text { Injuries occurring } \\
\text { at home (\%) }\end{array}$ & 43 & 61 & 75 \\
\hline Left eye (\%) & 60 & 34 & 50 \\
\hline Open globe injury (\%) & 80 & 17 & 75 \\
\hline Retinal injury (\%) & 50 & 42 & 38 \\
\hline $\begin{array}{l}\text { Number of surgeries } \\
\text { performed }\end{array}$ & $\begin{array}{l}\text { None: } 13 \% \text {, one: } \\
44 \% \text {, two: } 30 \% \text {, } \\
\text { three or more: } 13 \%\end{array}$ & $\begin{array}{l}\text { None: } 62 \% \text {, one: } \\
29 \% \text {, two: } 5 \% \text {, three } \\
\text { or more: } 3 \%\end{array}$ & $\begin{array}{l}\text { None: } 25 \% \text {, one: } 63 \% \text {, } \\
\text { two: } 13 \%\end{array}$ \\
\hline Initial visual acuity & $\begin{array}{l}\text { NLP to } 20 / 20 \text {; } \\
\text { median: } H M\end{array}$ & $\begin{array}{l}\text { NLP to } 20 / 25 \\
\text { median: } H M\end{array}$ & $\begin{array}{l}\text { HM to } 20 / 30 \text {; median: } \\
20 / 70\end{array}$ \\
\hline Final visual acuity & $\begin{array}{l}\text { NLP to } 20 / 20 \\
\text { median: } 20 / 70\end{array}$ & $\begin{array}{l}\text { NLP to } 20 / 20 \\
\text { median: } 20 / 70\end{array}$ & $\begin{array}{l}\text { LP to } 20 / 30 \text {; median: } \\
20 / 50\end{array}$ \\
\hline Improvement (\%) & 50 & 68 & 57 \\
\hline No change (\%) & 38 & 22 & 29 \\
\hline Deterioration (\%) & 12 & 11 & 14 \\
\hline $\begin{array}{l}\text { Eyes remaining legally } \\
\text { blind }(\%)\end{array}$ & 43 & 16 & 29 \\
\hline
\end{tabular}

In conclusion, bottles containing carbonated drinks can cause severe ocular trauma. Among patients with adequate follow up in the combined USEIR/HEIR/MEIR database, $26 \%$ of eyes remained legally blind. Injuries occur even if the bottle is handled properly, ${ }^{19}$ but the risk markedly increases if the bottle is not chilled or is improperly handled. ${ }^{13}$ The risk of

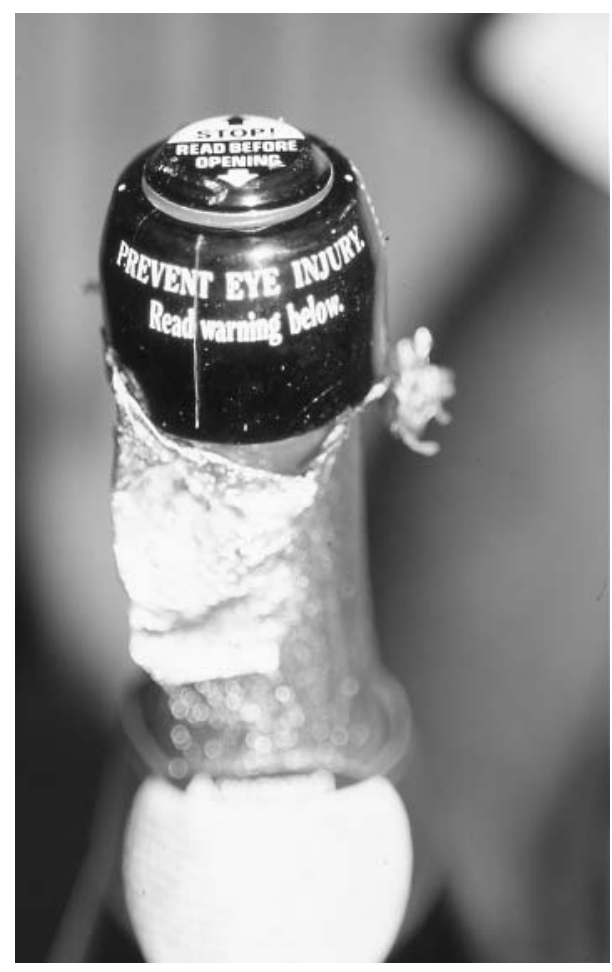

Figure 1 Following removal of the wrapping foil, warning cartoon and label on the top of the champagne bottle cork become visible, reminders of the risk of and the need to prevent eye injuries. ocular trauma is not restricted to the person handling the bottle: more than one fourth of patients in our combined database were bystanders. Trauma caused by the broken glass typically results in more severe damage, requires more surgical interventions, and has worse prognosis than that caused by flying bottle tops. Open globe injury can also result from broken prescription glasses.

There are several ways to reduce the injury risk. School campaigns should be waged since children are the most susceptible. ${ }^{114}$ The use of plastic bottles, metal cans, and plastic screws, rather than glass and pressed metal caps, is crucial. Conspicuous warning labels should be placed on all champagne bottles. Based on this study, we plan to approach manufacturers-or legislators if need be-in Hungary and request label placement, which serves the interest of the industry as well by reducing liability. The use of specialised opening tools (such as the PerfectPop, www.perfectpop.com) should also be encouraged since these also decrease the risk.

\section{ACKNOWLEDGEMENTS}

This research was supported by a department grant from Research to Prevent Blindness, Inc. The authors also want to thank Armando Meza, MD, Graciana Fuentes, MD, Daniel Jauregui, MD, Maria Gomez, MD, Mauricio Turati, MD, Manuel Garza, MD, and Adriana Solis, MD, for their contributions in collecting the Mexican data.

\section{Authors' affiliations}

F Kuhn, R Morris, University of Alabama at Birmingham, USA, University of Pécs, Hungary, and Helen Keller Foundation for Research and Education, Birmingham, AL, USA

V Mester, Mafraq Hospital, Abu Dhabi, United Arab Emirates

J Dalma, Mexican Eye Injury Registry, and Ophthalmology Service,

Hospital Angeles de las Lomas, Mexico, and Asociación para Evitar la Ceguera en México

Correspondence to: Ferenc Kuhn, MD, PhD, American Society of Ocular Trauma, 120111 th Avenue South, Suite 300, Birmingham, AL 35205, USA; fkuhn@mindspring.com

Accepted for publication 19 April 2003 


\section{REFERENCES}

1 Al Salem M, Sheriff SM. Ocular injuries from carbonated soft drink bottle explosions. Br J Ophthalmol 1984;68:281-3.

2 Gupta AK, Nadiger M, Moraes $O$. Ocular injury from a carbonated beverage bottle. J Pediatr Ophthalmol Strabismus 1980;17:394-5.

3 Mondino BJ, Brown SI, Grand MG. Ocular injuries from exploding beverage bottles. Arch Ophthalmol 1978;96:2040-1.

4 Kuhn F, Morris R, Witherspoon CD, et al. Serious fireworks-related eye injuries. Ophthalmic Epidemiol 2000;7:139-48.

5 May D, Kuhn F, Morris R, et al. The epidemiology of serious eye injuries from the United States Eye Injury Registry. Graefes Arch Clin Exp Ophthalmol 2000;238: 153-7

6 Kuhn F, Morris R, Witherspoon CD, et al. A standardized classification of ocular trauma terminology. Graefes Arch Clin Exp Ophthalmol 1996;234:399-403.

7 Mayes D, Andrews B. Exploding bottles. JAMA 1962;182:969-70.

8 Archer D, Galloway N. Champagne-cork injury to the eye. Lancet 1967;2:487-9.

9 Duerksen K, Albert D, Saulson R. Soda pop top ophthalmopathy. Am J Ophthalmol 1988;61:761-2.

10 Dunn JP Jr, Berger ST, Mondino BJ, et al. Ocular trauma caused by exploding glass bottles containing dry ice and water. Ophthalmic Surg 1990;21:628-31.

11 Fox KR. Ocular injuries from beverage bottles. Arch Ophthalmol 1979;97:975.
12 Grinbaum A, Ashkenazi I, Treister G, et al. Exploding bottles: eye injury due to yeast fermentation of an uncarbonated soft drink. Br J Ophthalmol 1994;78:883.

13 Keunen JE, Storimans CW. With an eye on the champagne cork. Ned Tijdschr Geneesk 1994; 138:2594-6.

14 Koval R, Teller J, Belkin M, et al. The Israeli Ocular Injuries Study. A nationwide collaborative study. Arch Ophthalmol 1988;106:776-80.

15 Leydhecker W. Augenverletzungen durch explodierde Getrankenflaschen. Klin Monatsbl Augenheilkd 1963;148:929-34.

16 Offutt R, Shine I. Perforating injuries of the eye due to glass. Ann Ophthalmol 1974; 7:357-63.

17 Overton BW. Eye injuries from exploding bottles. BMJ 1991;303:785

18 Savir H. Ocular injuries from exploding beverage bottles. Arch Ophthalmol 1979;97:1544.

19 Sellar PW, Johnston PB. Ocular injuries due to exploding bottles of carbonated drinks. BMJ 1991;303:176-7.

20 Sloan SH. Champagne cork injury to the eye. Trans Am Acad Ophthalmol Otolaryngol 1975;79:OP889-92.

21 Spang S, Hoh H, Ruprecht KW. Eye injuries caused by opening or explosion of beverage bottles. Ophthalmologe 1995;92:35-7.

22 Viestenz A, Kuchle M. Eye contusions caused by a bottle cap. A retrospective study based on the Erlangen Ocular Contusion Register. Ophthalmologe 2002;99:105-8.

23 Waikhom JS. Ocular injuries from beverage bottles. Arch Ophthalmol 1979;97:975.

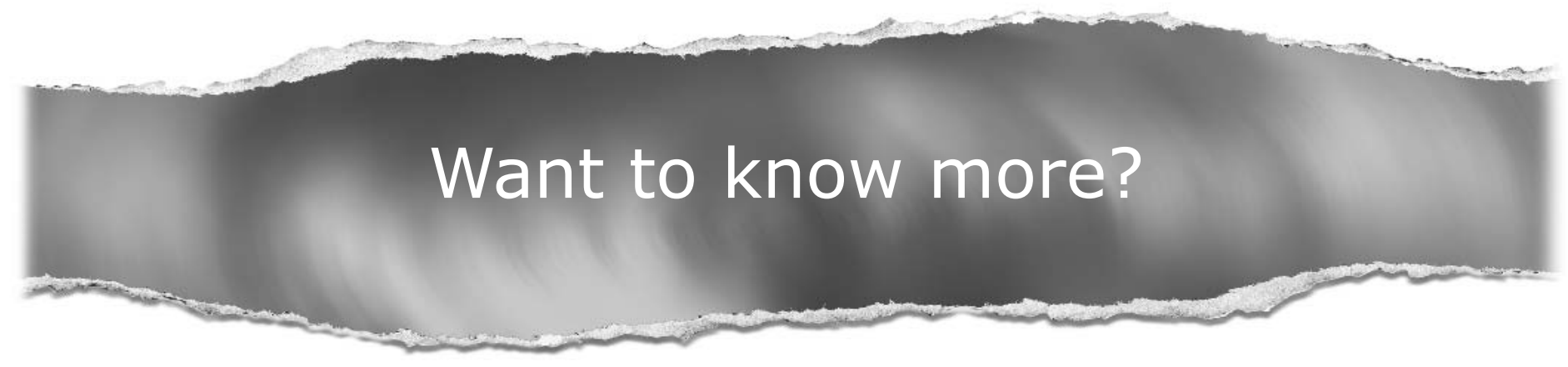

\section{Data supplements}

Limited space in printed journals means that interesting data and other material are often edited out of articles; however, limitless cyberspace means that we can include this information online. Look out for additional tables, references, illustrations, and (soon to appear) multimedia clips online!

\section{www.bjophthalmol.com}

